\title{
SER PROFESSOR DE FILOSOFIA: CONCEITUAÇÕES DE RECEPÇÃO FILOSÓFICA ${ }^{1}$
}

\author{
BEING A PHILOSOPHY TEACHER: CONCEPTIONS OF PHILOSOPHICAL RECEPTION
}

SER PROFESOR DE FILOSOFÍA: CONCEPCIONES DE RECEPCIÓN FILOSÓFICA

\author{
Fábio Antonio Gabriel \\ Doutor em educação pela Universidade Estadual de Ponta Grossa, SEED PR - Secretaria de Educação do \\ Paraná - Colégio Estadual Rio Branco - Santo Antonio da Platina PR \\ E-mail: fabioantoniogabriel@gmail.com. \\ Orcid: https://orcid.org/0000-0002-4990-4102
}

\author{
Ana Lúcia Pereira \\ Doutora em ensino de ciências e educação matemática, Universidade Estadual de Ponta Grossa. \\ E-mail: anabaccon@uepg.br \\ Orcid: https://orcid.org/0000-0003-0970-260X
}

\begin{abstract}
RESUMO
Este artigo enfoca as concepções acerca do entendimento de ser professor de Filosofia no Ensino Médio em relação à cultura de desvalorização dessa disciplina, tal como se descortina no cenário contemporâneo. Ao utilizar os conceitos fundamentais de recepção filosófica que trabalha a questão da relação entre a Filosofia e o cotidiano, esta pesquisa teve como objetivo identificar as concepções sobre o que é ser professor para um grupo de 208 professores de Filosofia da rede pública de ensino do estado do Paraná, Brasil. A pesquisa, de natureza qualitativa, conta com dados organizados e interpretados mediante procedimentos metodológicos da análise de conteúdo que tornaram possível a identificação de duas categorias centrais sobre o ser professor de Filosofia: uma relacionada ao compromisso político-social na docência; e outra, à identidade docente, ambas relativas à prática e ao ensino de Filosofia. Essa constatação revela alguns aspectos para compreender a identidade docente bem como a própria identidade da Filosofia.
\end{abstract}

Palavras-chave: Recepção filosófica. Ensino de filosofia. Formação de professores de filosofia.

\begin{abstract}
This paper focuses on the conceptions about the understanding of being a teacher of Philosophy in High School in relation to the culture of devaluation of this discipline, as it is revealed in the contemporary scenario. Through the use of the fundamental concepts of philosophical reception that works on the question of the relationship between Philosophy and everyday life, this research aimed to identify the conceptions about what it is to be a teacher for a group of 208 Philosophy teachers from the public school system of the state of Paraná, Brazil. The research, of a qualitative nature, relies on data organized and interpreted through methodological procedures of content analysis that made it possible to identify two central categories about being a Philosophy teacher: one related to the political-social commitment in teaching; and another to the teaching identity, both related to the practice and teaching of Philosophy. This finding reveals some aspects to understand the teaching identity as well as the identity of Philosophy.
\end{abstract}

Palavras-chave: Philosophical reception. Philosophy teaching. Philosophy teacher training.

1 O presente trabalho foi realizado com apoio da Coordenação de Aperfeiçoamento de Pessoal de Nível Superior (CAPES) e Fundação Araucária. 


\section{RESUMEN}

Este artículo se centra en las concepciones sobre el entendimiento de ser profesor de Filosofía en la Enseñanza Media en relación con la cultura de la desvalorización de esta asignatura, tal como se revela en el escenario contemporáneo. Al utilizar los conceptos fundamentales de recepción filosófica que trabaja en la cuestión de la relación entre la Filosofía y la vida cotidiana, esta investigación tuvo como objetivo identificar las concepciones sobre lo que es ser docente para un grupo de 208 docentes de Filosofía del sistema escolar público del estado. de Paraná, Brasil. La investigación, de carácter cualitativo, cuenta con datos organizados e interpretados mediante procedimientos metodológicos de análisis de contenido que hicieron posible la identificación de dos categorías centrales sobre ser profesor de Filosofía: una relacionada con el compromiso político-social en la docencia; y otro, a la identidad docente, ambas relativas a la práctica y a la enseñanza de la Filosofía. Esta corroboración revela algunos aspectos para comprender la identidad docente, así como la identidad de la Filosofía.

Palabras clave: Recepción Filosófica. Enseñanza de filosofía. Formación de profesores de filosofía.

\section{INTRODUÇÃO}

A sociedade contemporânea tem sofrido substanciais mudanças nas últimas décadas, e os efeitos dessas transformações têm afetado diretamente o contexto escolar, as relações que ali se desenvolvem, bem como o papel e a função dos sujeitos que fazem que a educação aconteça de fato. Dentre esses sujeitos, destacamos o professor que, imerso nesse contexto, assume diversos papéis e responsabilidades, que perpassam desde a construção do conhecimento até a construção de valores (VAILLANT; MARCELO, 2012). Nesse sentido, Ens e Donato (2011, p. 87) destacam que "[...] ser profissional do conhecimento na sociedade do conhecimento tornou-se uma ação complexa e em estado de constante tensão diante dos desafios impostos pela própria profissão de professor e pela sociedade".

Atrelado a esse cenário de mudanças, trazemos para o debate o papel do professor de Filosofia, que tem enfrentado não somente as transformações da sociedade contemporânea, mas também alguns golpes, desgastes e efeitos relacionados à medida provisória da Reforma do Ensino Médio, instituída na Lei № 13.415, de 16 de fevereiro de 2017, e aprovada recentemente.

Todo esse cenário nos coloca algumas questões: Qual é o papel do professor nesse contexto? O que se espera ou qual é o novo modelo de professor que precisamos para atuar neste novo século? Qual é o papel da Filosofia nesse contexto todo? Como o professor de Filosofia pode contribuir para a construção de visão de mundo e de ser humano com seus alunos? As respostas para essas questões ligam-se diretamente à visão 
que o próprio professor de Filosofia tem do mundo e do seu entendimento sobre o que é ser professor.

A compreensão da tarefa de ser professor de Filosofia depende muito do que se entenda por esse desempenho no âmbito da Filosofia. A ideia do que seja Filosofia evidencia, também, o que seja ensinar Filosofia. No Paraná, as Diretrizes Curriculares de Filosofia (PARANÁ, 2008) optam pelo ensino como criação de conceitos. Entender a Filosofia como criação de conceitos implica pensar a aula de Filosofia como o momento oportuno para uma experiência filosófica, em que o estudante do Ensino Médio adquire condições de, por meio da Filosofia, partir de suas experiências pessoais para relacioná-las com o seu cotidiano.

Partimos, assim, da hipótese de que a concepção de ser professor influencia a prática e a visão de mundo desse mesmo professor. Desse modo, no presente artigo, temos como objetivo analisar as concepções que professores de Filosofia têm sobre o que é ser professor. Abordamos, a seguir, uma revisão sobre formação de professores de Filosofia e seu ensino e sobre recepção filosófica. A metodologia subjacente ao estudo é, então, apresentada e os resultados da pesquisa analisados. Por fim, discutimos os resultados à luz do quadro conceitual aqui apresentado, à medida que lançam uma perspectiva crítica sobre as concepções sobre ser professor de Filosofia na sociedade contemporânea.

\section{Formação de professores de filosofia}

A disciplina de Filosofia transitou, diversas vezes, por um movimento pendular, ora entrando, ora saindo do curso de formação básica das futuras gerações. Nas atuais circunstâncias, a Filosofia retornou ao Ensino Médio e, diante desse retorno, somos motivados a pensar na formação de futuros professores de Filosofia.

Em revisões bibliográficas sobre ensino de Filosofia no Brasil, Perencini (2017) percebeu que, percentualmente, é tímido o número de publicações sobre ensino de Filosofia e sobre a formação do professor de Filosofia nos periódicos brasileiros, pois não chegou a 1\% o número de artigos e/ou textos analisados nos periódicos selecionados pelo autor. Além disso, a ideia de ensino de Filosofia trabalhada busca "[...] transmitir um conteúdo da tradição filosófica e no melhor método para fazê-lo, o que restringiu a 
possibilidade de pensar esse nível de aprendizado como uma experiência de pensamento" (PERENCINI, 2017, p. 35).

Tomazetti e Moraes (2016, p. 749) apontam que as disciplinas pedagógicas nos cursos de formação de professores acabam ficando em segundo plano, como se fossem apenas um cumprimento formal de exigências burocráticas para titular os acadêmicos como licenciados. As autoras remetem-se ao texto das Diretrizes Curriculares Nacionais (DCN) dos Cursos de Filosofia - Parecer CNE/CES N 492, de 3 de abril de 2001 (BRASIL, 2001) - para dissertar sobre os elementos propostos pela orientação das referidas diretrizes para a formação de professores de Filosofia. As pesquisadoras apresentam um quadro de competências e habilidades segundo as Diretrizes, das quais destacamos quatro:
1) capacitação para um modo especificamente filosófico de formular e propor soluções a problemas, nos diversos campos do conhecimento;
2) capacitação para análise, interpretação e comentário de textos teóricos, segundo os mais rigorosos procedimentos de técnica hermenêutica;
3) compreensão da importância das questões acerca do sentido e da significação da própria existência e das produções culturais;
4) capacitação de relacionar o exercício da crítica filosófica com a promoção integral da cidadania e com o respeito à pessoa, dentro da tradição de defesa dos direitos humanos. (TOMAZETTI; MORAES, 2016, p. 751).

Outro aspecto que podemos destacar ainda como um grande desafio na formação e na atuação do professor de Filosofia, destacado por Heuser (2010), é a dicotomia entre prática e teoria. Para que se consiga pensar a licenciatura em Filosofia de forma mais integrada, a autora indica a necessidade de superarem-se muros, a saber: licenciaturas que funcionam como bacharelados; preconceitos contra a docência (valoriza-se a pesquisa e desvaloriza-se a docência); dissociação entre produção filosófica e docência. Heuser (2010) aponta a importância de entender a atividade de formar novos professores como um problema filosófico, como um primeiro passo para se superarem esses muros.

Nesse sentido, Cerletti (2009), ao longo de sua obra, defende o argumento de que ensinar Filosofia exige que se problematize filosoficamente seu ensino: "Afirmamos que um ensino ‘filosófico' é aquele em que o filosofar é o motor de tal ensino; e que, enquanto atividade própria da filosofia, esse ensino enlaça o fazer filosofia com o sentido de sua transmissão"2 (CERLETTI, 2009, p. 21, grifo do autor). O entendimento de que é importante

\footnotetext{
${ }^{2}$ Assim como Baccon e Arruda (2015, p. 467), associamos o conceito de transmissão na presente pesquisa à ideia de "ideia de ensino", apresentada por Charlot (2005, p. 90, grifos do autor): "[...] um saber a transmitir, quaisquer que sejam as modalidades de transmissão, que podem ser magistrais ou passar por processos de ‘construção', de 'apropriação”.
} 
que o professor de Filosofia conduza seus alunos para uma experiência do filosofar (CARRILHO, 1987) permite-nos entender que a aula de Filosofia é o momento propício para uma experiência do pensamento. Assim, o professor de Filosofia é convidado a provocar seus alunos ao exercício do filosofar.

Enfim, são diversos os desafios diante da formação de professores de Filosofia. Talvez o desafio maior seja cumprir o proposto pelas DCN de Filosofia, que consistem em capacitar os futuros professores de Filosofia para proporem problemas e soluções de forma filosófica.

\section{Recepção filosófica: entre pensar, viver e agir}

Agnes Heller (1983) contribui para pensarmos sobre a experiência filosófica na medida em que trabalha a questão da relação entre Filosofia e cotidiano e, norteada pelo conceito de recepção filosófica, afirma que a máxima do filósofo consiste em atuar em conformidade com a própria teoria: "A filosofia não vivida não é autêntica, não cumpre a função da filosofia" (HELLER, 1983, p. 26). A filósofa afirma que toda Filosofia é crítica de uma forma de vida e concomitantemente também é uma "[...] sugestão de uma outra forma de vida" (HELLER, 1983, p. 27). Do mesmo modo, como entendemos que a Filosofia não pode ser apenas enciclopédica, Heller (1983, p. 33) critica a Filosofia quando é entendida apenas como material científico. A Filosofia, assim, ao ser ensinada, deve propiciar aos seus interlocutores uma experiência filosófica e não apenas o ensino enciclopédico de uma teoria. Para a autora:

A filosofia não é uma profissão: o ingresso no sistema filosófico é antes a elaboração da atitude orientada para o pensamento metódico-racional, a partir do ângulo da unidade do Bem e do Verdadeiro, do dever-ser. O aluno não deve se tornar filósofo, mas se apropriar ativamente da filosofia; qualquer que seja sua profissão, ele tem a possibilidade dessa apropriação. (HELLER, 1983, p. 25).

Heller (1983) divide o conceito de recepção filosófica em duas vertentes: recepção completa ou total; e recepção incompleta ou parcial. A recepção completa ou total da Filosofia consuma-se quando a Filosofia de um determinado pensador é apropriada pelo receptor, que busca harmonizar o pensar, o agir e o viver. A recepção completa-se em três tipos: o receptor estético, o entendedor e o receptor filosófico pleno (HELLER, 1983). 
Quando tal entendimento não ocorre, trata-se de uma recepção incompleta ou parcial, a qual corresponde apenas a um dos momentos ou à recepção de uma destas questões: como se deve pensar, como se deve agir e como se deve viver. A recepção parcial processase, também, em três tipos: recepção política, recepção iluminadora e recepção guia do conhecimento. O Quadro 1, a seguir, apresenta, com base nessas concepções, a descrição desses receptores.

Quadro 1 - Modos de recepção da Filosofia

\begin{tabular}{|c|c|c|}
\hline \multicolumn{2}{|c|}{ Modo de recepção } & Descrição \\
\hline \multirow{3}{*}{$\begin{array}{l}\text { Recepção } \\
\text { completa }\end{array}$} & $\begin{array}{l}\text { Receptor estético - } \\
\text { apropriação por meio da } \\
\text { forma. }\end{array}$ & $\begin{array}{l}\text { "A recepção estética da filosofia se dá pela } \\
\text { apropriação da forma da obra filosófica, que é } \\
\text { diferente da apropriação do sistema. Um sistema é } \\
\text { composto por várias obras. O receptor busca na } \\
\text { forma estética da obra de filosofia uma forma que se } \\
\text { adeque à sua recepção estética. [...]. O receptor } \\
\text { estético é aquele que vê a obra filosófica como algo } \\
\text { belo: por isso, a sua recepção será sempre catártica." } \\
\text { (HORN; MENDES, 2016, p. 288) }\end{array}$ \\
\hline & $\begin{array}{lll}\text { Receptor } & \text { entendedor } & - \\
\text { domínio } & \text { da } & \text { cultura } \\
\text { filosófica. } & & \end{array}$ & $\begin{array}{l}\text { "O receptor entendedor tem um amplo domínio da } \\
\text { cultura filosófica e a vê como parte orgânica da } \\
\text { cultura. Ele busca compreender e interpretar os } \\
\text { sistemas filosóficos, admirando seu caráter de obra } \\
\text { humana." (HORN; MENDES, 2016, p. 288). }\end{array}$ \\
\hline & $\begin{array}{l}\text { Receptor filosófico } \\
\text { apropriação do modus } \\
\text { operandi filosófico. }\end{array}$ & $\begin{array}{l}\text { "Na compreensão de Heller, o receptor filosófico é o } \\
\text { verdadeiro receptor da filosofia, pois, para se } \\
\text { apropriar filosoficamente da filosofia, ele escolhe } \\
\text { somente uma filosofia como utopia racional, uma } \\
\text { forma de vida e decide viver coerentemente de } \\
\text { acordo com aquela filosofia. O fundamento da } \\
\text { recepção filosófica é a compreensão que se faz a } \\
\text { partir da forma de vida do receptor, que é } \\
\text { determinada pelos problemas da vida cotidiana. A } \\
\text { recepção da filosofia pelo receptor é mediada pelas } \\
\text { experiências vividas que decorrem de seu próprio } \\
\text { mundo e sua relação com ele." (HORN; MENDES, } \\
2016, \text { p. 289). }\end{array}$ \\
\hline \multirow[t]{2}{*}{ Recepção parcial } & $\begin{array}{l}\text { Recepção política - reflete } \\
\text { como se deve agir. }\end{array}$ & $\begin{array}{l}\text { "A recepção política ocorre quando a recepção } \\
\text { filosófica parcial é guiada unicamente pelo 'reflete } \\
\text { como deves agir'. Nesse sentido, política significa } \\
\text { toda a atividade dirigida à transformação da realidade } \\
\text { social, e isso só é possível nas filosofias em que a } \\
\text { utopia é também uma utopia social, em que está } \\
\text { presente o confronto do dever-ser com o ser, fazendo } \\
\text { brotar as consequências sociais esperadas ou } \\
\text { almejadas." (HORN; MENDES, 2016, p. 290). }\end{array}$ \\
\hline & $\begin{array}{l}\text { Recepção iluminadora - } \\
\text { como se deve viver. }\end{array}$ & $\begin{array}{l}\text { "Na recepção filosófica parcial iluminadora, o } \\
\text { receptor isola o momento do 'como devo viver', } \\
\text { ignorando o 'como devo pensar' e 'como devo agir'. } \\
\text { O que ele busca é apenas dar sentido à própria vida, } \\
\text { não se importando com nenhuma generalização de } \\
\text { forma de vida oferecida pela filosofia. É uma recepção } \\
\text { sentimental, na qual o receptor busca na filosofia uma }\end{array}$ \\
\hline
\end{tabular}




\begin{tabular}{|l|l|l|}
\hline & & $\begin{array}{l}\text { forma de iluminar o sentido existencial de sua vida, } \\
\text { buscando respostas às perguntas, como, por } \\
\text { exemplo, por que estou no mundo? Qual é minha } \\
\text { missão neste mundo?" (HORN; MENDES, 2016, p. } \\
\text { 290). }\end{array}$ \\
\cline { 2 - 3 } & $\begin{array}{l}\text { Recepção guia do "A terceira forma de recepção parcial é, para Heller, } \\
\text { conhecimento - como } \\
\text { devo pensar. }\end{array}$ & $\begin{array}{l}\text { um tipo de recepção na qual o receptor se apropria do } \\
\text { momento 'reflete como devo pensar' e o transforma } \\
\text { em guia do conhecimento." (HORN; MENDES, 2016, p. } \\
\text { 291). }\end{array}$ \\
\hline
\end{tabular}

Fonte: Elaboração própria a partir de Horn e Mendes (2016).

A compreensão de Heller (1983, p. 34) ajuda-nos a pensar o professor de Filosofia como um filósofo e a sala de aula como espaço para um laboratório conceitual. Assim, o professor de Filosofia não é apenas um profissional que ensina Filosofia, mas é alguém que vive a Filosofia. A sala de aula é um convite a um exercício do pensamento e da problematização do ensino da Filosofia como um problema filosófico.

A próxima seção apresenta os métodos de pesquisa, seguidos pela análise e pela discussão das descobertas.

\section{O estudo}

A investigação, de natureza qualitativa (BOGDAN; BIKLEN, 1994), teve como sujeitos da pesquisa 208 professores de Filosofia da rede pública do estado do Paraná. Os dados foram coletados por meio de um questionário online (google.docs), contendo sete questões. Entretanto, como no presente artigo nosso objetivo é identificar e analisar as concepções que professores de Filosofia dispõem a respeito do que é ser professor, focamo-nos apenas nos dados referentes à primeira questão: "O que é ser professor para você?".

Para a organização e a análise dos dados coletados, utilizamos a metodologia de análise de conteúdo de Bardin (2011). Essa técnica auxilia na organização, na descrição e na interpretação do conteúdo de documentos e textos. Ela é organizada em três momentos principais: pré-análise, exploração do material e posterior tratamento dos resultados.

Após a pré-análise, para a organização da etapa de exploração do material e uniformização dos dados, contamos com o auxílio do software de análise qualitativa Atlas TI 7. Cabe ressaltar que, embora o uso desse software torne essa etapa do processo mais 
rápida e prática, a análise e a interpretação são de responsabilidade dos pesquisadores (KLÜBER, 2014).

\section{Achados}

Os principais achados que surgiram com base nas concepções sobre o que é ser professor para os professores de Filosofia pesquisados foram organizados em dois grupos. O primeiro deles reúne concepções sobre ser professor, relacionadas com o compromisso político-social na docência, quando se busca formar cidadãos críticos e transformadores, conforme destacado por Ens e Donato (2011). Também vai ao encontro das competências e das habilidades das DCN dos cursos de Filosofia, ao buscar promover, de forma integral, a cidadania e a tradição de defesa dos direitos humanos, conforme destacado por Tomazetti e Moraes (2016). Essas concepções, portanto, aparecem ancoradas na ideia do ser professor como um colaborador na formação do cidadão e do ser professor como um transformador do mundo.

A segunda descoberta-chave agrupa as concepções do ser professor que contempla aspectos da identidade docente, relativas à prática e ao ensino de Filosofia. Dizem respeito, assim, aos aspectos mais técnicos da profissão docente, acerca da ação do professor na sua prática cotidiana e com o ensino de Filosofia, conforme destacado por Kalsing (2012), Tomazetti e Moraes (2016), Perencini (2017) e Cerletti (2009). As concepções que compõem esse grupo aparecem ancoradas na ideia do ser professor como: mediador do conhecimento e no processo de ensino e aprendizagem; eterno estudioso e como profissional com diversos papéis.

Descrevemos esses aspectos a seguir, por meio de uma análise dos resultados e de discussões relacionadas. Extraímos os trechos discursivos diretos dos participantes da pesquisa como evidência de resultados da pesquisa. Como uma forma de preservar a confidencialidade dos participantes, adotamos um código para representar os professores, o qual será indicado pela letra "P” seguida por um número; desse modo, P1 representa o professor 1, P2 o professor 2, e assim sucessivamente.

\section{Compromisso político-social na docência}


O primeiro grupo de descobertas agrega as unidades de análises sobre a concepção de ser professor como um colaborador na formação do cidadão. Essas unidades de análise apontam que, para esse grupo de professores, o ser professor é buscar transformar o sujeito aluno em cidadão crítico, para que esse aluno compreenda, atue e faça a diferença no mundo, como sugerem os excertos das falas a seguir (apresentamos algumas da amostra total):

P5: É colaborar com a formação do cidadão crítico.

P14: É buscar a compreensão do mundo que nos rodeia e, posteriormente, repassar este conhecimento para os demais para que também compreendam o mundo ou, ao menos, passem a buscar essa compreensão.

P106: É poder ser coadjuvante na formação cidadã de seres humanos.

$P$ 120: Aparenta ser parte de um instrumento de formação de um futuro cidadão.

P168: É estar comprometido com a emancipação e a criatividade de todos aqueles que são confiados a nós.

P82: Ajudar no desenvolvimento cultural dos jovens e levá-los a pensar o seu papel no mundo de forma crítica.

As falas dos professores enfatizam a questão do ser professor como sendo um colaborador na formação do cidadão para que possa atuar de forma crítica e possa compreender o mundo que o rodeia. Relacionam-se, também, às competências e às habilidades apresentadas pelas DCN dos cursos de Filosofia, pois apontam para a promoção integral da cidadania e para o respeito à pessoa humana (TOMAZETTI; MORAES, 2016).

Podemos destacar que as falas dos professores também estão relacionadas às competências e às habilidades das DCN dos cursos de Filosofia, na medida em que buscam capacitar o professor de Filosofia “[...] para um modo especificamente filosófico de formular e propor soluções a problemas, nos diversos campos do conhecimento" (BRASIL, 2001, p. 50), bem como que ele tenha a “[...] compreensão da importância das questões acerca do sentido e da significação da própria existência e das produções culturais" (BRASIL, 2001, p. 50).

A segunda unidade de análise que compõe esse primeiro grupo de descobertas caracteriza o ser professor como um transformador do mundo, conforme sugerem as falas a seguir:

P8: É contribuir para o mundo através não apenas da mera transmissão de conhecimentos, mas levar em consideração um conhecimento que faço o aluno refletir sobre sua condição e se incomode para transformá-lo.

P35: Ser agente de transformação.

P51: É ter um papel fundamental na sociedade, ensinar para a vida.

P59: Ser professor é ser um agente transformador da sociedade. 
P170: Estar disposto a transformar a realidade, transformando a si próprio a cada nova reflexão.

P179: É ter o poder de contribuir para a formação do indivíduo com o compromisso de assumir seu papel no progresso da humanidade.

Esses excertos vão ao encontro dos aspectos abordados nas Diretrizes Curriculares da Educação Básica (PARANÁ, 2008), na medida em que se busca compreender o sentido e a significação da própria existência no mundo e transformá-la, visto que o professor busca conduzir os seus alunos para uma experiência do filosofar (CARRILHO, 1987).

As falas dos professores evidenciadas nesse grupo também estão relacionadas às competências e às habilidades apresentadas nas DCN dos cursos de Filosofia (TOMAZETTI; MORAES, 2016). Os professores veem-se como agentes transformadores da sociedade e ou do mundo e buscam com que os alunos tenham compreensão e encontrem sentido na sua existência no contexto social e cultural, a partir do "exercício da crítica filosófica".

Entretanto, para que tal compromisso se estabeleça, é necessário que o professor disponha de uma formação e preparação para atuar nesta atual sociedade, caracterizada por mudanças e incertezas, e que seja capaz de enfrentar os diversos desafios impostos (IMBERNÓN, 2011).

\section{Identidade docente, prática e ensino de filosofia}

As concepções que compõem o segundo grupo aparecem ancoradas na ideia do ser professor como: mediador do conhecimento no processo de ensino e aprendizagem; eterno estudioso e como profissional com diversos papéis.

As unidades de análise que caracterizam o ser professor como um mediador do conhecimento no processo de ensino e aprendizagem são compostas por significantes relacionados à prática e ao ensino de Filosofia, bem como à identidade docente. A primeira unidade de análise identificada foi transmissão, como sugerem os excertos que seguem:

P36: Saber transmitir aos seus alunos conhecimentos, que os levam a ter progresso em seus estudos.

P 85: Transmitir conhecimentos e receber conhecimento constante.

P98: Ter a oportunidade de transmitir conhecimento.

P118: Transmitir conhecimentos, saber e demonstrar o encanto com a disciplina.

P159: Ser professor é professar o saber e procurar transmiti-lo com a maior seriedade possível. 
Embora a palavra "transmissão", utilizada por esses professores, apareça ligada à construção do conhecimento, é necessária uma certa cautela com o seu uso, pois essa ideia de transmitir conhecimentos remete a uma visão tradicionalista de concepção de ensino, relacionada à racionalidade técnica (IMBERNÓN, 2011).

A segunda unidade de análise identificada nesse grupo foi “ensinar”. Esse é um conceito que necessita de cuidado, visto que também envolve vários aspectos da ação docente. Em se tratando do ensino de Filosofia, para ensinar é importante que o professor de Filosofia busque conduzir seus alunos para uma experiência do filosofar. Conforme destaca Carrilho (1987), como um momento propício para uma experiência do pensamento, para o exercício do filosofar. Para alguns dos docentes:

P3: Professor vai muito além de transmitir o seu conhecimento em sala de aula e sim garantir o bom ensino do aluno.

P97: Estar sempre disposta a ensinar e ajudar meus alunos na busca pelo conhecimento e pela reflexão.

P185: Ser um professor é ensinar.

P204: Viver e compartilhar experiências novas e enriquecedoras todo dia.

Do mesmo modo, o ato de ensinar Filosofia não pode ser apenas enciclopédico, conforme destaca Heller (1983). Ao ser ensinada, a Filosofia deve propiciar aos seus interlocutores uma experiência filosófica. Com exceção de P185, que também foi muito genérico, podemos perceber que $\mathrm{P}_{3}, \mathrm{P}_{97}$ e $\mathrm{P} 204$ relacionam o ato de ensinar com conhecimento e reflexão. Essa visão também pode ser observada nas falas dos professores a seguir, quando relacionam o ser professor com a unidade de análise "aprendizado".

P25: É contribuir para que o aluno se interesse e aprenda sobre os valores importantes que devem ser compartilhados.

P40: Ser professor é ter a capacidade de compreender que outros necessitam de conhecer o mundo e suas circunstâncias, e que essa transposição didática tenha que acontecer sempre.

P128: Um aprendizado constante para a vida.

P145: Educar, mostrar visões de mundo diversas e construir independência.

P167: Um educador e também um pesquisador, leitor assíduo e aprendiz, pois sempre aprendemos com os alunos e com a prática do ensino-aprendizagem.

P187: Criar situações de aprendizagem, humanização do ser humano.

Essas falas também revelam aspectos de um ensino de Filosofia não de forma enciclopédica, conforme destaca Heller (1983), pois esses docentes buscam estabelecer uma relação entre a filosofia e o cotidiano, por meio da aprendizagem.

A quarta unidade de análise identificada nesse grupo para o ser professor é “mediador", como destacam os professores a seguir: 
P66: Mediador de conhecimentos e formador de seres humanos reflexivos.

P61: Ser facilitador.

P63: Mediador do conhecimento.

P144: É ser um mediador. Também aprendemos com nossos alunos.

P169: Identificando questões, ampliando possibilidades, mediando a relação com o conteúdo e os saberes por meio da pesquisa, do diálogo e das práticas.

P181: Dividir experiências e conhecimento, construir ponte entre o desconhecido, a ciência e a realidade do aluno e da comunidade escolar. Estar junto aprendendo e ensinando é fazer parte de um processo contínuo e dinâmico científico, empírico e contrastante que nos apresenta a cada dia mais verdades veladas e reveladas e as infinitas possibilidades de contestações.

Para alguns professores, a concepção de ser professor como um mediador aparece relacionada à ideia de "ensinar e aprender", conforme os seguintes excertos:

P117: É ensinar e aprender, ter a missão e comprometimento com a formação integral do aluno.

P157: Um agente que ensina e aprende.

P126: É a oportunidade de aprender cada dia e contribuir para a humanização dos seres humanos na busca da felicidade e do bem viver.

P189: Saber reconhecer em cada aluno suas dificuldades e limitações e buscar oferecer um caminho de aprendizagem e ensinamentos.

P186: Compartilhar conhecimentos.

P197: Trocar conhecimentos.

Em se tratando da unidade de análises sobre o ser professor como um "mediador do conhecimento no processo de ensino e aprendizagem", encontramos alguns professores que relacionam o ser professor com a construção de relações com o saber, com o mundo e com os outros, conforme destaca Charlot (2000).

P48: Além de contribuir para o processo ensino aprendizagem dos alunos, é uma oportunidade de exercitar a análise crítica, reflexão, formulação/atualização de conceitos, busca da sabedoria e o diálogo.

P68: Então, ser professor constitui-se num estado de possibilidades de construções do indivíduo nas relações com o saber, com o mundo e entre os indivíduos (estudante e o professor) no espaço de sala de aula.

P75: Ser professor é poder propiciar ao aluno a oportunidade da aquisição do conhecimento e o aprendizado através da múltipla troca de experiências entre professor e aluno.

P139: Proporcionar o desenvolvimento e crescimento do aluno a partir das reflexões e conteúdos da disciplina ministrada.

P150: O sujeito que serve como intermediário ao processo de desmecanização do pensamento e ação por meio da apresentação de perspectivas/óticas a respeito do mundo e da existência.

P195: Se posicionar perante o mundo, a vida, a sociedade, a individualidade.

Essas falas vão ao encontro da "ideia de ensino" apresentada por Charlot (2005, p. 90), na medida em que os docentes buscam construir uma relação com o saber (CHARLOT, 2000). O sujeito, ao estar no mundo, é obrigado a aprender, e essa relação dá-se com o mundo, com o outro e com ele mesmo. O indivíduo, vai, desse modo, construindo e se 
apropriando do conhecimento. Essa ideia ainda pode ser observada nas falas dos professores a partir da unidade de análise “Conhecimento e autonomia intelectual”.

P87: É ser obrigado a revisitar constantemente o conhecimento.

P97: Estar sempre disposta a ensinar e ajudar meus alunos na busca pelo conhecimento e pela reflexão.

P107: É poder auxiliar os educandos na construção de seus conhecimentos, tanto para a vida profissional quanto para a vida pessoal.

P114: É motivar a ação intelectual dos outros. Indicar caminhos para pensar criticamente e resolver problemas. É transformar o mundo por intermédio do processo ensino-aprendizagem. É conduzir à liberdade intelectual.

P125: Facilitar o processo de aprendizagem para o aluno, dando ferramentas para que ele possa exercitar o pensamento.

P198: Conduzir o educando a criar sua própria autonomia intelectual, motivá-lo a desenvolver o próprio potencial (competências).

P121: Relacionar com os alunos visando seu desenvolvimento autônomo, cultural, racional, social, emocional, cognitivo... enfim integral.

P22: Educador é um guia na construção do conhecimento.

P 158: Orientar e provar simultaneamente acerca da natureza e relevância do saber.

P201: Proporcionar as condições que os alunos possam refletir, de fato, filosoficamente.

Podemos perceber ainda nessa categoria que o modo de transmitir o conteúdo filosófico, apontado pelos professores, não busca restringir “[...] a possibilidade de pensar esse nível de aprendizado como uma experiência de pensamento" (PERENCINI, 2017, p. 35). Ao contrário, propicia condições para que o aluno estabeleça novas conexões, sinta, perceba, pense, aja e se coloque no mundo como um sujeito da história.

O segundo aspecto identificado no grupo identidade docente, relativa à prática e ao ensino de Filosofia está relacionado a questões mais pessoais. Há uma relação do sujeito com o conhecimento que aparece a partir da unidade de análise "eterno estudioso". Essa unidade é representativa pela busca constante do professor pelo conhecimento, pela sua relação com o saber a partir de sua ligação consigo mesmo ou com o outro, conforme destaca Charlot (2000). Isso foi evidenciado pelos professores da seguinte forma:

P19: É estar sempre estudando.

P32: É um sujeito que deve buscar constantemente o conhecimento.

P10: Ser professor é realização.

P33: Uma grande missão muito especial.

P81: Ser professor é exercitar um dado saber na convivência com o outro de modo a estimulá-lo.

P142: É uma forma de apoiar as pessoas em relação a sua realização pessoal.

P148: Ampliar minha realidade e das pessoas ao redor.

P191: Ser professor é ser um parceiro na busca pela construção de sentido.

P42: Ser professor é um ato de doação no qual considero inerente à minha existência. 
Podemos perceber nessas falas que, para esses docentes, o ser professor está diretamente relacionado com a própria pessoa, ao investimento pessoal.

O terceiro aspecto identificado no grupo sobre a identidade docente, relativa à prática e ao ensino de Filosofia traz o ser professor como um profissional com diversos papéis, que perpassam a questão do conhecimento e do ato de ensinar em si, relacionados ao lugar que as pessoas podem ocupar em suas vidas, ou, ainda, à missão, à vocação. Isso foi evidenciado nas falas dos professores a seguir:

P11: Ser professor é ser de tudo um pouco, amiga, conselheira, irmã, mãe, problematizar o mundo.

P46: É uma missão, vocação.

P84: Uma luta diária.

P95: É idealismo e confiança no ser humano.

P96: Mais que uma profissão.

P101: Um desafio, pois hoje está complicado se manter na área.

P123: Penso que é ser luz para os alunos e para essa sociedade que se encontra na treva da ignorância.

P129: É ter a capacidade de impactar as pessoas de maneira que impossibilite a vigência do senso comum, dos preconceitos, da alienação.

P151: É aquele que leva um material novo, a cada dia, para cativar o aluno.

P154: Ser professora é construir um laço efetivo e afetivo entre os alunos e alunas e o conhecimento.

P180: É poder orientar e ajudar o estudante a mergulhar no mar fascinante que é o conhecimento. Embora, essa jornada só pode ser realizada pelo próprio indivíduo. P196: Ser um instigador de curiosidades. Potenciar a curiosidade da juventude para novos conhecimentos.

Dentro desse aspecto do ser professor como um profissional com diversos papéis, alguns professores parecem se afastar do foco do ensino da Filosofia, apresentando uma concepção muito vaga.

P43: Vivenciar diariamente a felicidade.

P69: É mostrar uma infinidade de caminhos.

P76: Gratidão.

P78: Uma arte.

P79: Presente de Deus.

P199: É ser portador de esperança.

P202: É ser um modelo a ser seguido.

Conforme destaca Carrilho (1987), conduzir os alunos a uma experiência do filosofar é de extrema importância, não apenas como algo teórico, mas uma unidade que busca pensar, agir e viver, conforme destaca Heller (1983). Entrentanto, não se pode esquecer que esse ensino jamais pode ter caracter doutrinador.

É importante destacar que encontramos somente duas falas sobre ser professor em nossos dados que continham aspectos diferenciados das categorias aqui apresentadas. Uma delas relacionava a profissão de ser professor como "não reconhecida" e outra 
atrelada a uma forma de "remuneração" e ou "subsistência", conforme evidenciam as falas a seguir:

P1: Pertencer a uma das profissões mais importantes, porém, menos reconhecida. P188: Ser professor é para mim uma forma de remuneração/subsistência apenas. Todavia, gosto de lecionar.

Após essa análise dos dados, partimos para uma discussão crítica dos resultados. Iniciamos por empregar o conceito de recepção filosófica de Heller (1983). E, para fornecer uma reflexão mais abrangente sobre os resultados, utilizamos o trabalho de outros teóricos.

\section{Discussão}

Ao buscar superar a visão bacharelesca da formação de professores de Filosofia, o propósito de seu ensino seria relacionado à prática do cotidiano, permitindo aos sujeitos, a partir do seu contato com a Filosofia, dispor de aptidões para se tornarem sujeitos pensantes e críticos (KALSING, 2012). O professor de Filosofia conduzir seus alunos para uma experiência do filosofar (CARRILHO, 1987) permite-nos entender a aula de Filosofia como um momento propício para uma experiência do pensamento. Assim, o professor de Filosofia é convidado a provocar seus alunos ao exercício do filosofar.

No caso desta pesquisa, foi particularmente visível que os participantes apresentaram uma concepção sobre ser professor não só como um colaborador na formação do cidadão, mas com o desejo de transformar o mundo ao seu redor, conforme ficou evidenciado no primeiro grupo de categorias. Nesse aspecto, podemos inferir que a Filosofia aparece como reflexão e como espaço para o pensamento crítico nas falas dos professores que compõem o primeiro grupo. Isso evidencia também o compromisso político-social na docência de que o professor precisa dispor para formar cidadãos críticos e transformadores, para viver na sociedade contemporânea, caracterizada por mudanças, incertezas e desafios (ENS; DONATO, 2011).

Em relação aos aspectos da recepção completa da Filosofia apresentada por Heller (1983), destacamos que não foi possível de ser detectada nesta pesquisa, pois não é somente na fala daquilo que o sujeito pensa que tal aspecto pode ser percebido, mas também com base no seu viver e no seu agir, e de como esse mesmo sujeito incorpora um 
entendimento à sua existência. Nossos dados revelam que muitos professores aqui pesquisados possuem um discurso filosófico, mas, como não acompanhamos a respectiva ação docente no cotidiano, não podemos afirmar que os professores em referência lograram uma recepção filosófica total, pois não observamos como a Filosofia atinge de fato as suas vidas.

Entretanto, pudemos perceber nas falas dos professores, mesmo que isoladamente, aspectos da recepção filosófica, caracterizado por Heller (1983), a saber: utopia racional, na medida em que as falas dos professores revelam indícios de "[...] como se deve pensar, colocando a razão a serviço da solução dos problemas humanos reais, dos carecimentos" (HORN; MENDES, 2016, p. 287); teoria social ou da sociedade, pois também encontramos indícios nas falas dos professores sobre o "[...] como se deve agir, considerando a necessidade de atender o carecimento de orientação por mudança social e construção de uma sociedade de novo tipo - antítese à forma de vida do capitalismo -, à luz do Bem e da Verdade" (HORN; MENDES, 2016, p. 287); e filosofia da vida presente, a partir das falas dos professores que evidenciam aspectos de "[...] como se deve viver, buscando responder como é possível viver a partir 'do hoje', viver na perspectiva de como dar respostas aos problemas existenciais/sociais da vida humana" (HORN; MENDES, 2016, p. 287).

Os aspectos identificados no nosso estudo podem também ser relacionados aos aspectos da recepção filosófica parcial, apresentada por Heller (1983), na medida em que alguns professores, ao ensinarem Filosofia, não buscam apenas ensinar uma teoria, mas, sim, dela apropriar-se de acordo com a forma de pensar sobre a própria existência.

Nosso estudo revela, ainda, que alguns professores apresentaram concepções relacionadas a um habitus (BOURDIEU, 2007) de ensino típico ao de ensino e de aprendizagem mais convencionais, não como uma experiência de pensamento, conforme aponta Perencini (2017). Destacamos esses aspectos visto que alguns professores enfatizaram a questão do ser professor relacionada a transmitir conhecimentos a partir de uma visão tradicional de ensino. Entretanto, a proposta argumentativa que defendemos e apontada por Cerletti (2009) não seria apenas transmitir conhecimentos, mas ensinar Filosofia problematizando filosoficamente seu ensino. Por isso, é importante que o professor de Filosofia conduza seus alunos para uma experiência do filosofar, conforme destaca Carrilho (1987). 
Em relação ao grupo de professores que relacionaram o ser professor como um eterno estudioso, podemos inferir que a concepção sobre ser professor, para esses docentes, apresenta traços de uma relação com o saber (CHARLOT, 2000), que tem como foco a relação do sujeito consigo mesmo.

Para o grupo que aponta o ser professor atrelado ao "profissional com diversos papéis", podemos destacar que é importante o professor desenvolver a capacidade subjetiva de relacionar-se com outros mundos, conforme destacam Tomazetti e Benetti (2012). Entretanto, há de tomar-se o cuidado de não querer impor a sua maneira de compreender a própria Filosofia como um dogma, como uma doutrina. Destacamos isso, pois a fala do professor P202, ao relacionar o ser professor com o "ser um modelo a ser seguido", abre margem para esse tipo de inferência.

Assim como Horn e Mendes (2016, p. 293), acreditamos que "[...] toda recepção tem sua importância e valor uma vez que abarca de alguma forma as perguntas: como se deve pensar? Como se deve agir? Como se deve viver?". Ao pensarmos nessas três perguntas como condutoras da ação, seja do professor, seja do aluno, seja de qualquer cidadão, certamente elas colocam o sujeito em um estado de reflexão.

Nesse sentido, a Filosofia integra a vida do professor, porque é por ele desfrutada, faz uso dela para despertar nos alunos o que Freire (1981) chama de conscientização ou consciência crítica. Ao considerar que a educação bancária obstrui a criatividade dos sujeitos, buscando domesticar as suas ações e evitar que tenham condições de criar significados no meio em que vivem, Freire (1981) propõe um tipo de educação problemática, de natureza dialógica. A educação problemática possibilita e considera as criações e as contribuições dos indivíduos como atos de aprendizagem significativos e críticos. Seu objetivo, portanto, é capacitar o aluno para que disponha de condições de analisar criticamente a realidade social que o cerca e possa agir sobre ela. Como uma forma de empoderamento, a educação problemática proposta por Freire (1981) não enfatiza apenas a agência crítica, mas também a cidadania ativa e democrática.

A recepção filosófica, assim, revela uma identidade na Filosofia que demarca de fato a sua função - em outras palavras, de fazer que o sujeito se coloque como pensador no exercício do filosofar. O ensino da Filosofia e a prática do professor revelam aspectos de que, ao incorporar e relacionar a Filosofia ao seu cotidiano, o docente exerça de fato o seu 
papel de educador, de professor, tornando a si e a seus alunos sujeitos de fato empoderados.

\section{CONSIDERAÇÕES FINAIS}

Ao buscarmos, na teoria da recepção filosófica, uma compreensão para analisar a concepção de ser professor para o grupo de professores aqui pesquisado, acreditamos que poderiam nos auxiliar na análise de alguns aspectos da identidade da Filosofia, bem como na identidade do professor de Filosofia. Em relação à Filosofia, a teoria da recepção filosófica de Heller (1983) aponta que a Filosofia não deve ser algo apenas teórico, mas é preciso criar uma unidade entre pensar, agir e viver. Desse modo, o professor de Filosofia não é alguém que apenas ensina ou transmite uma teoria, mas é convidado a desfrutar, a viver a Filosofia na sua própria existência. A Filosofia, assim, não seria uma profissão, mas um apropriar-se de uma forma de pensar para a própria existência.

Nesse sentido, o professor deve fazer uso da Filosofia para buscar desenvolver nos alunos a conscientização proposta por Freire (1981), para que o aluno aprenda a dispor de condições teóricas, a colaborar para a construção de uma sociedade democrática e a sentirse estimulado para o exercício da cidadania, tornando-se, assim, um sujeito empoderado. Isso permite-nos entender a aula de Filosofia como um momento propício para uma experiência do pensamento e do exercício do filosofar.

Os professores de Filosofia aqui pesquisados, ao desejarem "colaborar para a formação do cidadão", "transformar o mundo", “ensinar”, “mediar” e que o aluno "construa conhecimento e autonomia intelectual", anseiam por formar os alunos como cidadãos críticos e conscientes, para transformar o mundo, colocando-os como centro da mudança transformadora (GIROUX, 1999). Isso pode estar atrelado ao seu próprio desejo de formar para a emancipação, de mudar as relações de poder entre os agentes, principalmente para aqueles que estão sujeitos a uma cultura de dominação há muito tempo (FREIRE, 1981). Podemos destacar que a teoria da recepção filosófica nos permite identificar na Filosofia aspectos que contribuem para o seu ensino e para a construção da identidade docente do professor, na medida em que busca incorporá-la na sua própria existência. No presente estudo, isso ficou mais evidenciado no grupo de professores que 
pensam para além de si, que deram indícios de que buscam relacionar a Filosofia ao seu cotidiano - no seu pensar, no seu agir e no seu viver.

Iniciamos este artigo fazendo uma análise de conjuntura dos enfrentamentos e dos desgastes que a disciplina de Filosofia vem sofrendo nos últimos tempos e o encerramos destacando alguns aspectos para a prática e para a política. As concepções sobre "ser professor" dos docentes aqui pesquisados apareceram ancoradas em dois grupos: o "compromisso político-social na docência" (que busca formar cidadãos críticos e transformadores) e a "identidade docente, relativas à prática e ao ensino de Filosofia". Ao aproximarmos as concepções do ser professor com os conceitos ou tipos de recepção filosófica, identificamos alguns aspectos da sua identidade docente. Para alguns docentes, ser professor permeia a recepção filosófica como uma "utopia racional", pois buscam relacionar a Filosofia com o cotidiano por meio do pensar, perseguindo sempre uma solução dos problemas humanos reais; outros, com a "teoria social”, ao exporem indícios de como se deve agir para se promover a mudança social e a construção de uma sociedade defendida por Freire (1981), contrária ao estilo de vida defendido pelo capitalismo; outros, como a "filosofia da vida presente", na medida em que evidenciam aspectos de como se deve viver, a partir "do hoje", buscando oferecer respostas aos problemas existenciais/sociais da vida humana.

Essa relação possibilitou-nos apontar que o grupo de professores que ancoraram o ser professor com o compromisso político-social na docência revelam aspectos de formação e de prática privilegiando a educação que busca a conscientização, conforme destaca Freire $(1981,2006)$. Tal constatação também foi identificada nas falas de alguns professores caracterizados no segundo grupo que continha aspectos da "identidade docente, relativas à prática e ao ensino de filosofia”, como ensinamento, aprendizagem, conhecimento intelectual e mediação. Entretanto, nesse grupo, também identificamos alguns aspectos de identidade docente que revelam indícios de formação ancorados nos modelos da racionalidade técnica, que permeia a profissão docente há tanto tempo (IMBERNÓN, 2011), tendenciando, como já apontamos, na contramão do sentido de transmissão defendido por Cerletti (2009). Nesse grupo, também identificamos professores que contemplam o foco no próprio docente e na relação que esse mesmo professor constrói consigo mesmo; e outro grupo que vê o ser professor como um profissional que desempenha diversos papéis. 
Em relação à política, nosso estudo revela que, embora toda pressão e todo desgaste provocado seja por meio de medidas provisórias, leis, etc., a Filosofia ainda exerce um papel essencial na educação dos jovens, pois ainda é uma disciplina que busca desenvolver a conscientização crítica e o despertar da consciência. Por isso, talvez, a disciplina perturbe tanto aqueles que ocupam um cargo político, pois, como diria Heller (1983, p. xx), “[...] a filosofia não tem nenhum poder; mas os que detêm o poder temem mais do que tudo os que pensam com sua própria cabeça".

Pensar na Filosofia a partir dos conceitos de recepção filosófica abre-nos um novo olhar para essa disciplina e para o seu ensino, pois nos possibilita ver os professores desenvolvedores de uma educação problemática, como agentes críticos e sujeitos empoderados (FREIRE, 1981, 2006, 2007) que buscam promover o empoderamento de outros, a cidadania ativa e a democracia.

Embora as concepções sobre ser professor apresentadas neste artigo representem uma amostra significativa de professores de Filosofia, uma pesquisa futura beneficiar-se-ia de uma abordagem mais aprofundada de como os professores buscam relacionar a Filosofia com o seu cotidiano, ou seja, como esse professor, de fato, faz uso da recepção filosófica na sua vida.

\section{REFERÊNCIAS}

BACCON, A. L. P.; ARRUDA, S. M. Estilos de gestão da sala de aula: uma análise a partir da ação docente. Práxis Educativa, Ponta Grossa, v. 10, n. 2, jul./dez. 2015. p. 463-487. DOI: https://doi.org/10.5212/PraxEduc.v.10i2.0010.

BARDIN, L. Análise de conteúdo. São Paulo: Edições 70, 2011.

BODGAN, R.; BIKLEN, S. Investigação qualitativa em educação: uma introdução à teoria e aos métodos. Portugal: Porto Editora, 1994.

BOURDIEU, P. A economia das trocas simbólicas. São Paulo: Perspectiva, 2007.

BRASIL. Lei $N^{\circ} 13.415$, de 16 de fevereiro de 2017. Altera as Leis $N^{\circ 5} 9.394$, de 20 de dezembro de 1996, que estabelece as diretrizes e bases da educação nacional, e 11.494, de 20 de junho 2007, que regulamenta o Fundo de Manutenção e Desenvolvimento da Educação Básica e de Valorização dos Profissionais da Educação, a Consolidação das Leis do Trabalho - CLT, aprovada pelo Decreto-Lei no 5.452, de 10 de maio de 1943, e o DecretoLei no 236, de 28 de fevereiro de 1967; revoga a Lei no 11.161, de 5 de agosto de 2005; e institui a Política de Fomento à Implementação de Escolas de Ensino Médio em Tempo Integral. Diário Oficial da União: seção 1, Brasília, DF, n. 35, p. 1-3, 17 fev. 2017. 
BRASIL. Parecer No 492, de 3 de abril de 2001. Diretrizes Curriculares Nacionais dos cursos de Filosofia, História, Geografia, Serviço Social, Comunicação Social, Ciências Sociais, Letras, Biblioteconomia, Arquivologia e Museologia. Diário Oficial da União: Seção 1E, Brasília, DF, n. 131, p. 50, 9 jul. 2001.

CARRILHO, M. M. Razão e transmissão da filosofia. Lisboa: Imprensa Nacional Casa da Moeda, 1987.

CERLETTI, Alejandro. 0 ensino de filosofia como problema filosófico. Tradução Ingrid Muller Xavier. Belo Horizonte: Autêntica, 2009.

CHARLOT, B. Da relação com o saber: elementos para uma teoria. Porto Alegre: Artmed, 2000.

CHARLOT, B. Relação com o saber, formação dos professores e globalização: questões para a educação hoje. Porto Alegre: Artmed, 2005.

ENS, R. T.; DONATO, S. P. Ser professor e formar professores: tensões e incertezas contemporâneas. In: ENS, R. T.; BEHRENS, M. A. (Orgs.). Ser professor: formação e os desafios na docência. Curitiba: Champagnat, 2011. p. 79-100.

FREIRE, P. Educação como prática da liberdade. 29. ed. Rio de Janeiro: Paz e Terra, 2006. FREIRE, P. Pedagogia do oprimido. 9. ed. Rio de Janeiro: Paz \& Terra, 1981.

FREIRE, P. Pedagogia da autonomia: saberes necessários à prática educativa. 35. ed. São Paulo: Paz e Terra, 2007. (Coleção Leitura).

GIROUX, H. A. Os professores como intelectuais: rumo a uma pedagogia crítica da aprendizagem. Porto Alegre: Artmed, 1999.

HELLER, A. A filosofia radical. Brasília: Brasiliense, 1983.

HEUSER, E. M. D. Muros do estágio e da formação de professores de filosofia. Saberes, Natal, v. 2, n. 5, ago. 2010. p. 18-28.

HORN, G. B.; MENDES, A. A. P. Ensino de filosofia: método e recepção filosófica em Agnes Heller. Educar em Revista, Curitiba, n. 62, out./dez. 2016, p. 279-294.

IMBERNÓN, F. Formação docente e profissional: formar-se para a mudança e a incerteza. 9. ed. São Paulo: Cortez, 2011.

KALSING, R. S. Filosofia na escola e na formação de professores: por quê? para quê? Poiésis, Tubarão, v. 5, número especial, jul./dez. 2012. p. 109-125.

KLÜBER, T. E. Atlas/t.i como instrumento de análise de pesquisa qualitativa de abordagem fenomenológica. Educação Temática Digital, v. 16, n. 1, jan./abr. 2014. p. 5-23. 
PARANÁ. Secretaria de Educação do Estado do Paraná. Departamento de educação básica. Diretrizes curriculares da educação básica: filosofia. Curitiba: Secretária de Estado da Educação do Paraná, 2008.

PERENCINI, T. B. A formação dos professores em filosofia no Brasil: restrição de pensamentos e testemunho. Filosofia e Educação [RFE], Campinas, v. 9, n. 2, jun./set. 2017. p. 23-47.

TOMAZETTI, E. M.; BENETTI, C. C. Formação do professor de filosofia: entre o ensino e a aprendizagem. Revista Diálogo Educacional, Curitiba, v. 12, n. 37, set./dez. 2012 p. 10271043.

TOMAZETTI, E. M.; MORAES, S. B. A. Formação do professor de filosofia: entre o saber e o fazer. Revista Eventos Pedagógicos, Sinop, v. 7, n. 2, jun./jul. 2016. p. 744-758.

VAILLANT, D.; MARCELO, C. Ensinando a ensinar: as quatro etapas de uma aprendizagem. Curitiba: UTFPR, 2012.

Recebido em: 30/05/2020

Parecer em: 27/07/2020

Aprovado em: 03/08/2020 